( Т. Ю. Киричок, д.т.н., професор, Є. Г. Сухіна, аспірантка, НТУУ «КПІ імені Ігоря Сікорського», Київ, Україна, Ж. Т. Кажмуратов, здобувач, Казахстан

\title{
КОМПЛЕКСНЕ ОЦІНЮВАННЯ ЧУТЛИВОСТІ ЕЛЕКТРОФІЗИЧНИХ ПОКАЗНИКІВ ЗНОШУВАННЯ БАНКНОТ
}

\begin{abstract}
У статті аналізується взаємозв'язок електрофізичних властивостей зразків банкнот різних валют та ступеню їх зношування. Проведено дослідження параметрів, таких, як поверхневий та об'ємний опір, ємність і тангенс кута діелектричних втрат для банкнот трьох типів валют. Результати досліджень показують, що електрофізичні властивості є мірою зношування банкнот. Визначено найбільш чутливі показники та представлено перспективу використання електрофізичних властивостей банкнот з метою оцінювання ступеню їх зношування.
\end{abstract}

\section{Ключові слова: банкноти; зношування; зносостійкість; банкнотний папір; електрофізичні властивості.}

\section{Постановка проблеми}

Зносостійкість банкнотної продукції забезпечується на всіх етапах її виробництва, на кожному з яких отримують набір споживацьких ознак, які в кінцевому підсумку формують зносостійкісний комплекс готової банкноти, що виявляється в забезпеченні стійкості основи та ї̈ поліграфічного оформлення, а також у збереженні захисних ознак банкнот упродовж всього терміну знаходження їх в обігу.

Найвагомішим чинником, що забезпечує технологічні та споживацькі властивості банкнот є матеріал основи, що використовується для їх виготовлення. Матеріал паперової основи, з якого виготовляються банкноти та технологічні особливості виробниц- тва паперу самі по собі формують первинні зносостійкісні ознаки банкнот.

У процесі теоретичного і експериментального вивчення процесів зношування банкнот постає проблема пошуку методологічної основи об'єктивного оцінювання і контролю зносостійкості банкнот, зокрема, формуванням комплексного показника, а також виявлення та розроблення методів застосування нових показників зношеності [1, 2]. Експериментально встановлено зміни поверхневого та об'ємного опору, діелектричної проникності та тангенса кута діелектричних втрат під час зношування зразків банкнот, а також їх залежність від рівноважної вологості паперу та застосовуваних технологічних процесів. 
У попередніх дослідженнях експериментально визначено технологічні основи контролю зміни якості банкнот та за зміною їх структурних та поверхневих властивостей, які базуються на теоретичному обґрунтуванні впливу неоднорідності структури даного продукту на характер залежностей його електрофізичних параметрів, що можуть бути використані як індикатор зношеності банкнот $[1,2]$. Встановлено кореляційний зв'язок між електрофізичними показниками банкнот української гривні, такими як поверхневий та об'ємний опір, ємність, тангенс кута діелектричних втрат, - та рівнем їх фізичного зносу. Також визначено номінальні значення даних величин, що $є$ критеріями зношених банкнот, які не підлягають подальшому обігу.

\section{Мета роботи}

Дослідження механізмів формування та прогнозування зміни електрофізичних властивостей банкнот різних валют у процесі обігу та застосування цих властивостей як критеріїв евентуальної зносостійкості банкнот.

\section{Аналіз попередніх досліджень}

В основі сучасних технологічних рішень щодо підвищення зносостійкості банкнот пропонується, перш за все, підвищення стійкості банкнот до забруднення. Для різних країн світу кількість банкнот, що вилучається за рахунок забруднення варіюється в межах 64-81 \% від загальної маси вилучених банкнот, в той час як для українських банкнот даний показник $\epsilon$ істотно вищим і складає 89, 19 \% [3].
Усі процеси зношування банкнотного паперу перебувають в тісній кореляції з його поверхневими властивостями. У процесі зношення основи одночасно відбувається деформація міжволоконних зв'язків і міжмолекулярна взаємодія забруднювальних речовин з волокнами паперу (особливо на його поверхні), що підсилюється механічними деформаціями різного роду. До того ж у процесі зношування за рахунок контактного способу дії на банкноти зменшується стійкість поліграфічного оформлення банкнотної основи. Завдяки таким процесам відбувається накопичення забруднюючих речовин на поверхні та у порах банкнотного паперу. Загалом темп такого зношування залежить від здатності поверхневого шару банкнотної основи протистояти процесу дифузії дисперсійних шарів бруду. Забруднення відбувається шляхом адсорбування водорозчинного та жироподібного бруду волокнами целюлози, здійснюється його накопичення в порах бавовняної основи, які до забруднення заповнені були повітрям [4]. Отже, за рахунок зношування збільшується кількість струмопровідних включень паперу.

Як дисперсна система, банкнотний папір неминуче містить певну кількість струмопровідних включень, кількість яких збільшується під час технологічного процесу задруковування та за рахунок процесів зношування.

Електропровідність самого паперу виникає за рахунок таких факторів:

- Гігроскопічність паперу, обумовлена як наявністю полярних 
гідроксилів, що мають здатність притягувати полярні молекули води, так і капілярним характером структури волокнистого матеріалу. Адсорбована вода, що містить сліди електроліту, $\epsilon$ основною причиною електропровідності паперу. Через наявність полярних гідроксильних груп -ОН, що орієнтуються в електричному полі навколо одинарного зв'язку, виявляється ефект поляризації [6].

- Наявність в складі паперу включень золи, частка якої в банкнотному папері складає понад $2 \%$ маси. Частина металів, які містяться в золі, утримуються безпосередньо молекулами целюлози у вигляді катіонів за рахунок іонно-обмінної реакції [5];

- Електропровідність банкнотного паперу підсилюється введенням у композицію хімічних домішок, синтетичних, металізованих захисних волокон та стрічок [6]. У банкноті, як готовому виробі, електропровідність збільшується за рахунок використання металізованого компоненту в фарбовому пігменті.

Адгезія бруду до поверхні банкноти у процесі зношування відбувається за рахунок механічних та фізико-хімічних взаємодій. Перші обумовлені морфологічними особливостями поверхні частинок бруду і банкноти, їі структурою та пористістю. Другі виникають за рахунок надмірної вільної енергії між контактувальними поверхнями, яка $є$ наслідком міжмолекулярної взаємодії за рахунок сил Ван дер Ваальса, електростатичних сил та хемосорбції на поверхні волокон основи.
Слід також зазначити, що повітряні пори паперу мають меншу електричну міцність, ніж клітковина, і заміщення повітря в порах іншими більш електропровідними рідкими або твердими речовинами у процесі зношування різко зменшує електричну міцність паперу.

Аналізуючи вищенаведену інформацію, можна сказати, що провідність банкноти забезпечується інтегральною величиною провідностей її еквівалентних шарів, а саме: еквівалентним шаром целюлозних волокон, еквівалентного шару пор, еквівалентного шару поверхневого та об'ємного просочування. У процесі задруковування банкнотної основи додаються також еквівалентні шари поліграфічних фарб усіх видів, у процесі зношування - шар бруду.

\section{Результати проведених досліджень}

3 метою розробки комплексних практичних рекомендацій для оцінювання показника зносостійкості банкнот за об'єкт дослідження було обрано зразки банкнот Казахстанських тенге (номінал $200 \mathrm{KZT}$ ), банкнот Єврозони (номінал 10 EUR) та банкнот української гривні (номінал 2 UAH), які було відібрано 3 обігу та поділено на 4 групи відповідно до рівня їх фізичного зносу (1 - нові банкноти, 4 банкноти 3 максимально погіршеними характеристиками). Вибір низьких номіналів банкнот обумовлений інтенсивністю їх використання.

Для визначення змін електропровідності паперу у процесі зношування проведено вимірю- 
вання об'ємної та поверхневої електропровідності. Вимірювання об'ємної провідності, що зазвичай застосовується для визначення структурних змін матеріалів, проводилось у напрямку, що $€$ перпендикулярним до поверхні аркуша за використання стандартної методики [7] $з$ вагою електроду напруги у 6 кг (рис. 1).

Еквівалентна електрична схема об'ємного опору банкноти може бути представлена у вигляді електричного кола послідовно з'єднаних резисторів, опір яких дорівнює опорам різних складових банкноти $\mathrm{R}_{\mathrm{i}}$ (рис. 2 , a). Об'ємний опір банкноти $\mathrm{R}_{\mathrm{b}}^{\text {volume }}$ може бути визначений:

$$
\mathrm{R}_{\mathrm{b}}^{\text {volume }}=\sum_{\mathrm{i}=1}^{\mathrm{n}} \mathrm{R}_{\mathrm{i}}
$$

де $\mathrm{R}_{\mathrm{i}}$ - кількість структурних складових банкнотного паперу.

$$
\begin{aligned}
& \mathrm{R}_{\mathrm{b}}^{\text {volume }}=\mathrm{R}_{\text {fiber }}+\mathrm{R}_{\text {str.el. }}+ \\
& +\mathrm{R}_{\text {pores }}+\mathrm{R}_{\text {surf.sizing }}+ \\
& +\mathrm{R}_{\text {vol.sizing }}+\mathrm{R}_{\text {soil }}+\mathrm{R}_{\text {ink }},
\end{aligned}
$$

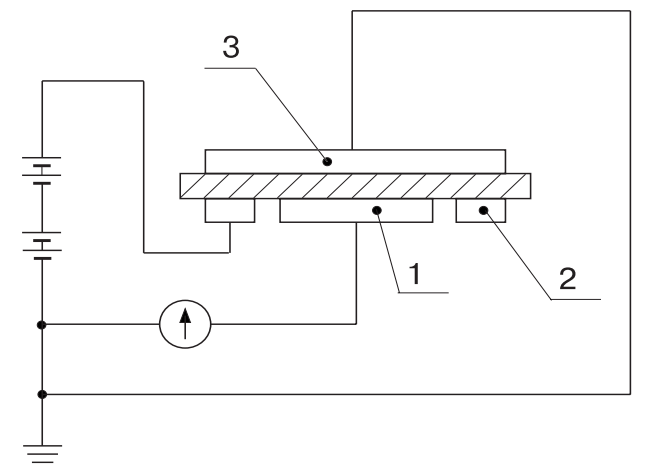

Рис. 1. Принципова схема з'єднання захищених електродів для вимірювання питомого об'ємного опору: 1 - вимірювальний електрод; 2 - захисний електрод; 3 - електрод напруги [7] де $\mathrm{R}_{\mathrm{fiber}}-$ опір целюлозних волокон; $R_{\text {str.el. }}$ - опір захисних включень паперу (синтетичних волокон, металізованих волокон, захисних стрічок, тощо); $\mathrm{R}_{\text {pores. }}$ - опір пор паперу, що заповнені повітрям; $\mathrm{R}_{\text {surf.sizing, }}$ $\mathrm{R}_{\text {vol.sizing }}$ - опори, що визначається речовинами поверхневого та об'ємного проклеювання відповідно, $\mathrm{R}_{\text {soil }}$ - опір, що визначається адсорбованими поверхнею паперу забрудненням, $R_{\text {ink }}$ - опір, що визначається поліграфічним оформленням банкнот.

Для визначення стійкості поверхні банкнотного паперу до забруднення було використано показник поверхневої електропровідності. Оскільки під час вимірювання поверхневого опору струм проходить через поверхневий шар та включає струм через об'єм зразка [5], то еквівалентна електрична схема поверхневого опору банкнотного паперу може бути подана як електричне коло паралельно з'єднаних резисторів, опір яких дорівнює опорам різних складових банкнотного паперу (рис. 2). 
Поверхневий опір банкнотного паперу може бути визначений:

$$
\frac{1}{R b_{p}^{\text {surface }}}=\sum_{i=1}^{n} \frac{1}{R_{i}}
$$

де $\mathrm{n}$ - кількість структурних складових банкнотного паперу.

$$
\begin{aligned}
& \frac{1}{\mathrm{R}_{\mathrm{b}}^{\text {surface }}}= \\
& =\frac{1}{\mathrm{R}_{\text {fiber }}+\mathrm{R}_{\text {str.el. }}+\mathrm{R}_{\text {pores }}+\mathrm{R}_{\text {vol.sizing }}}+ \\
& +\frac{1}{\mathrm{R}_{\text {surf.sizing }}}+\frac{1}{\mathrm{R}_{\text {soil }}}+\frac{1}{\mathrm{R}_{\text {ink }}} .
\end{aligned}
$$

де $\mathrm{R}_{\mathrm{fiber}}$ - опір целюлозних волокон; $R_{\text {str.el. }}$ - опір захисних включень паперу (синтетичних волокон, металізованих волокон, захисних стрічок, тощо); $\mathrm{R}_{\text {pores. }}$ - опір пор паперу, що заповнені повітрям; $R_{\text {surf.sizing, }}$ $\mathrm{R}_{\text {vol.sizing, }}$ - опори, що визначається речовинами поверхневого та об'ємного проклеювання відповідно, $\mathrm{R}_{\text {soil }}$ - опір, що визначається адсорбованими по-

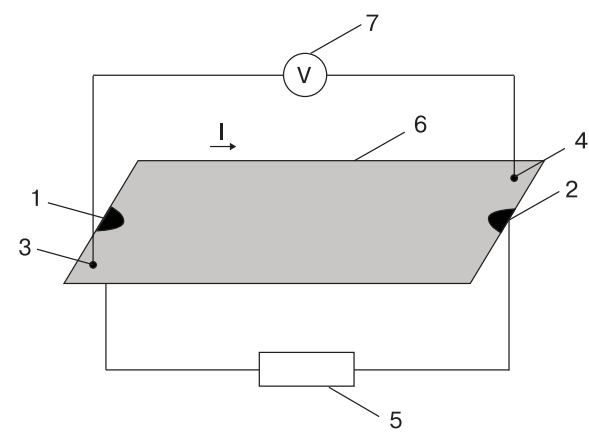

a верхнею паперу забрудненням, $\mathrm{R}_{\text {ink }}$ - опір, що визначається поліграфічним оформленням банкнот.

Вимірювання поверхневого опору було проведено згідно експериментальної методики, що полягає у вимірюванні напруги між крайовими частинами банкнот під час прикладення до суміжних крайових частин напруги сталої величини (рис. 2, а) [4].

Оскільки опір ділянки паперу, що вимірюється, суттєво більший за вхідний опір мультиметра M830Buz, то еквівалентна схема вимірювання може бути спрощено представлена у вигляді резистивного дільника напруги (рис. 3, б). Враховуючи закон Ома для еквівалентної електричної схеми маємо:

$$
\begin{gathered}
U_{v}=U \frac{R_{v}}{R_{b}+R_{v}} . \\
R_{b}=R_{v} \frac{U}{U_{v}}-R_{v} .
\end{gathered}
$$

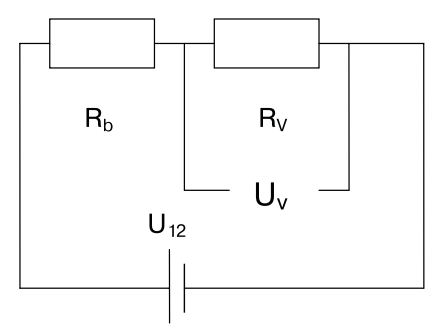

Рис. 2. Вимірювання поверхневого опору: а - схематичне зображення досліду: 1, 2 - точки прикладання напруги, 3, 4- точки вимірювання спаду напруги, 5 - блок живлення (NES-75-24), 6 - експериментальний зразок, 7 - мультиметр (M830Buz); б - еквівалентна електрична схема вимірювань: $U_{12}-$ прикладена напруга $\left(U_{12}=10 \mathrm{~B}\right), \mathrm{R}_{\mathrm{v}}-$ вхідний опір вольтметра $\left(R_{v}=1 \mathrm{MOM}\right), R_{b}$ - опір ділянки банкноти 


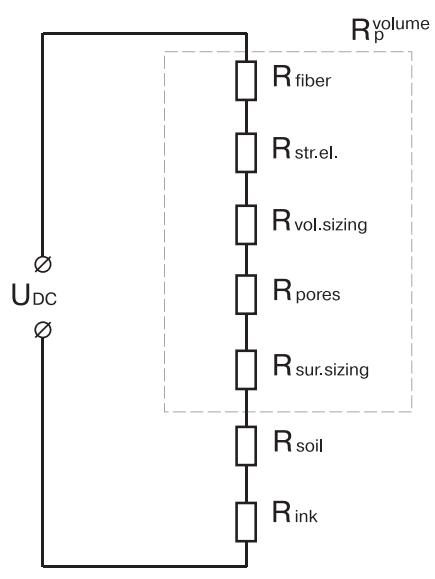

a

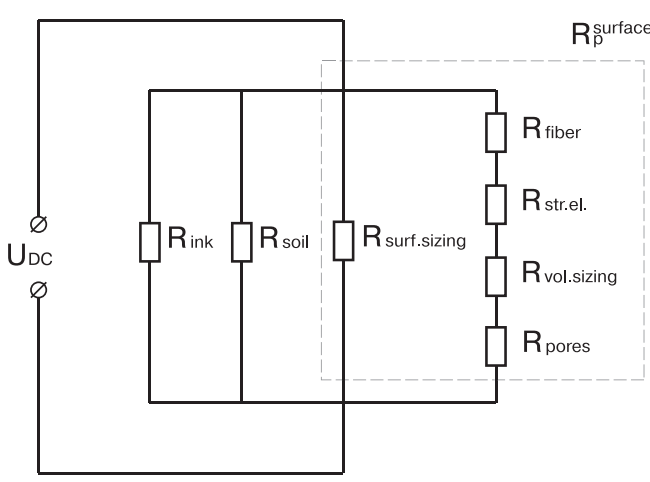

б

Рис. 3. Еквівалентна електрична схема банкноти: а - об'ємний опір;

б - поверхневий опір

у разі прикладання змінної напруги UAC еквівалентну електричну схему паперу можна подати як послідовно з'єднані конденсатори змінної ємності, що відповідають еквівалентним шарам паперу, згаданим раніше.

На рис. 3 наведено еквівалентні електричні схеми банкнот при вимірюванні поверхневого та об'ємного опорів.

Вимірювання ємності та тангенсу кута діелектричних втрат здійснено за допомогою цифрового вимірювача ємності Е8-4 при прикладенні змінної напруги частотою 1 кГц за схемою, що представлена на рис. 4.

Еквівалентні електричні схеми банкнот під час вимірювання ємності та кута діелектричних втрат представлено на рис. 5 .

3 огляду на вплив температури та відносної вологості повітря на характеристики волокнистих матеріалів, перед початком вимірювань проводилася акліматизація зразків протягом 24 год. при температурі $22 \pm 0,1^{\circ} \mathrm{C}$, відносній вологості 50,0 $\pm 2,0 \%$ (ГОСТ 13523-78).

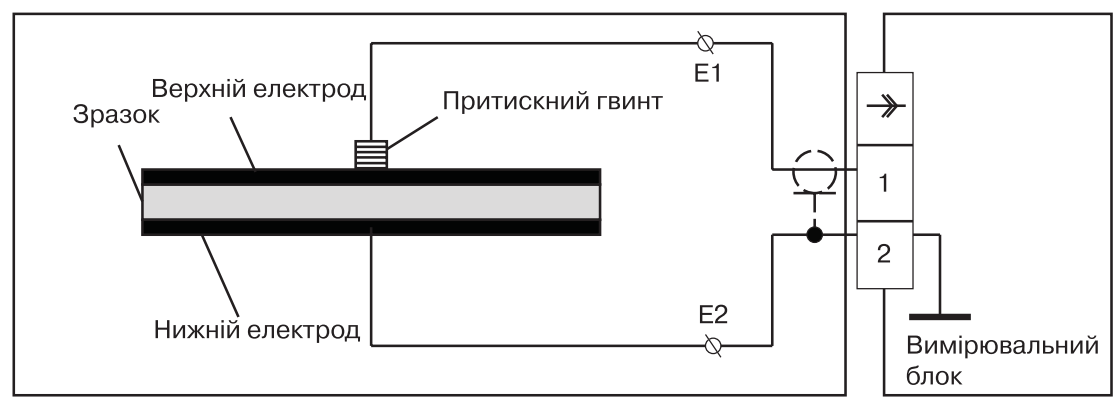

Рис. 4. Схема підключення електродів вимірювального блоку цифрового вимірювача ємності до зразка 
Однією із важливих метрологічних характеристик $€$ чутливість вимірювального приладу (засобу вимірювання) - відношення зміни сигналу на виході вимірювального приладу до зміни вимірюваної величини, що викликає зміну вихідного сигналу. Враховуючи, що зміною вимірюваної величини під час наших досліджень було віднесення банкноти до певної групи зношеності, чутливість досліджуваних електрофізичних параметрів як показників зношеності визначалася як їх відносна зміна, що розраховувалась для кожного 3 досліджуваних електрофізичних параметрів кожної валюти за формулою:

$$
\Delta x_{i k}=\frac{\left|x_{i j k}-x_{i 0 k}\right|}{x_{i 0 k}} \cdot 100 \%,
$$

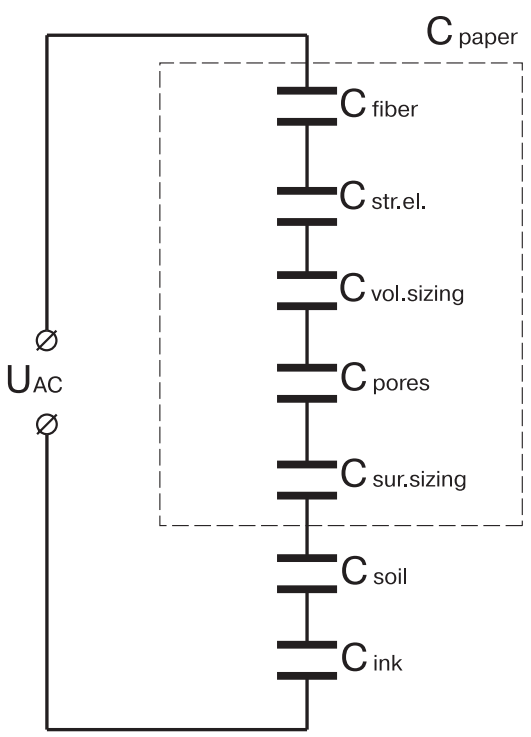

a де i - порядковий номер електрофізичного параметра; j — група зношеності (у нашому дослідженні $\mathrm{j}=\overline{1,4}$ ); $\mathrm{k}$ - порядковий номер валюти досліджуваних зразків; $\mathrm{x}_{\mathrm{iOk}}$ - середнє значення і-го електрофізичного параметра для незношених зразків k-ї валюти (1 група), $x_{\text {ijk }}-$ ceреднє значення і-го електрофізичного параметра для зразків, віднесених до ј-ї групи зношеності k-ї валюти. В табл. наведено значення чутливості показників для 4-ї групи зношеності, тобто для вилучення банкнот з обігу.

Для визначення доцільності використання і-го електрофізичного параметра як показника зношеності різних валют використано підходи до формування комплексного показника якості

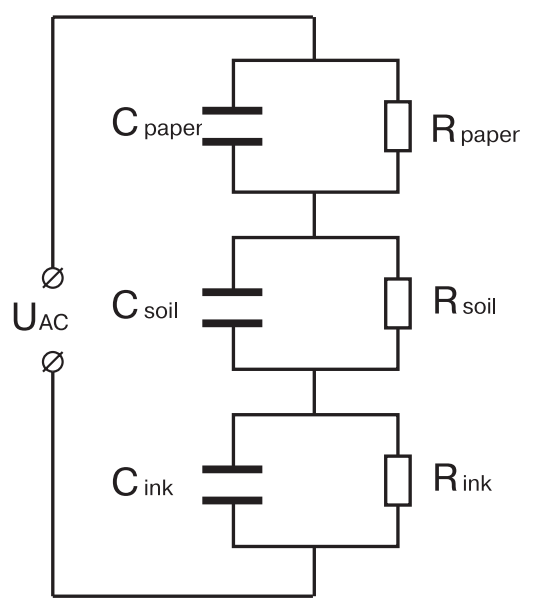

Рис. 5. Еквівалентна електрична схема паперу: а - ємність; б - тангенс кута діелектричних втрат 
(у нашому випадку - чутливості) на основі функції корисності [2]

$$
F\left(x_{i}\right)=\sum_{k=1}^{m} \omega_{k} \frac{\Delta x_{i k}}{\Delta x_{\max i}},
$$

де $\mathrm{F}\left(\mathrm{x}_{\mathrm{i}}\right)$ - комплексний показник чутливості і-го електрофізичного параметра; m - кількість валют досліджуваних зразків (у нашому дослідженні $m=3$ ); $\Delta \mathrm{x}_{\mathrm{ik}}$ - відносна зміна і-го електрофізичного параметра для k-ї валюти, визначена за формулою (7); $\Delta x_{\text {maxi }}$ - базове значення зміни і-го електрофізичного параметра за всіма досліджуваними валютами,

$$
\Delta \mathrm{x}_{\max \mathrm{i}}=\max _{\mathrm{k}} \Delta \mathrm{x}_{\mathrm{ik}}, \mathrm{k}=\overline{1, \mathrm{~m}} ; \omega_{\mathrm{k}}-\text { ва- }
$$

говий коефіцієнт k-ї валюти, що може бути визначений експерт-

ним опитуванням, $\sum_{\mathrm{k}=1}^{\mathrm{m}} \omega_{\mathrm{k}}=1$. У до-

слідженні прийнято, всі валюти $€$ рівноважними.

На рис. 6 зображено отримані експериментально залежності досліджуваних показників від ступеню зношування зразків банкнот.
3 табл. видно, що поверхневий опір є найбільш чутливим індикатором зношеності банкнот. Його використання обумовлене необхідністю оцінки ступеню забруднення банкнот. Для всіх валют, що досліджувались, відбулась також значна зміна об'ємного опору, що є обумовленою структурними змінами композитних шарів, що містяться в структурі банкнот. Зміна ємності і кута діелектричних втрат є менш значними.

\section{Висновки}

В результаті проведеного дослідження теоретично обгрунтовано взаємозв'язок електрофізичних параметрів банкнот різних валют та ступеню їх зношеності, розроблено інструментальний спосіб визначення ступеню забрудненості банкнот, представлено методологічні основи максимально об'єктивного оцінювання ступеню зношування банкнот.

Зміни електрофізичних параметрів банкнот загалом визначаються типом та орієнтацією целюлозних волокон в основі, властивостями поверхневого та

Чутливість електрофізичних показників зношеності банкнот

\begin{tabular}{|l|c|c|c|c|}
\hline \multicolumn{1}{|c|}{ Валюта зразка, k } & $\begin{array}{c}\text { Зміна по- } \\
\text { верхневого } \\
\text { опору, \% }\end{array}$ & $\begin{array}{c}\text { Зміна } \\
\text { об'ємного } \\
\text { опору, \% }\end{array}$ & $\begin{array}{c}\text { Зміна } \\
\text { ємності, \% }\end{array}$ & $\begin{array}{c}\text { Зміна tg } \delta, \\
\%\end{array}$ \\
\hline KZT & 97,4 & 93,4 & 13,9 & 4,3 \\
\hline EUR & 97,2 & 83,5 & 33,8 & 43,4 \\
\hline UAH & 95,9 & 89,5 & 1,4 & 120,1 \\
\hline $\begin{array}{l}\text { Комплексний показник } \\
\text { чутливості і-го електро- } \\
\text { фізичного параметра }\end{array}$ & 2,98 & 2,85 & 1,45 & 1,40 \\
\hline
\end{tabular}


об'ємного просочування, наявності захисних включень, поліграфічним оформленням та ступенем зношування. Через порушення структурної цілісності внаслідок зношування збільшується повітропроникність та пористість паперу, порушується герметизація волокон целюлози, сформована під час виготовлення банкноти, частково вивільняються зв'язані просочувальни- ми речовинами гідрофільні групи волокон целюлози, тому суттєво збільшується відносна рівноважна вологість паперу, i, як наслідок, зменшується опір як волокон, так і банкнотного паперу в цілому; відбувається загальне зменшення діелектричної проникності.

Найбільш чутливим до зношеності параметром $€$ поверхневий опір банкнот.

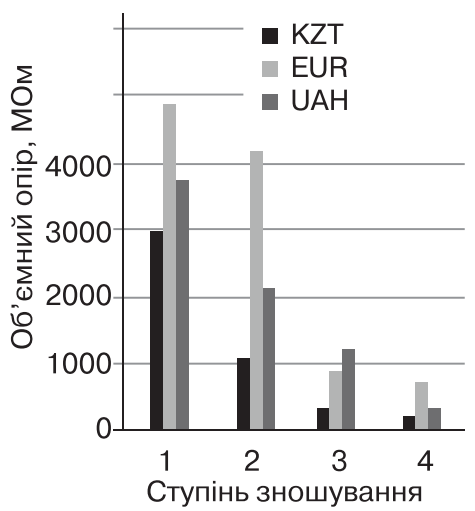

б

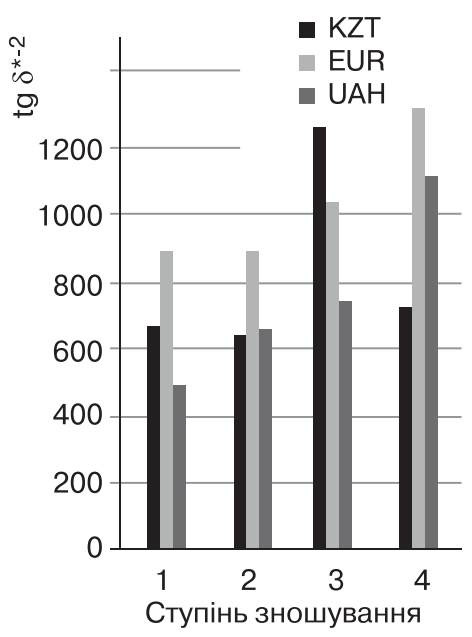

$\Gamma$

Рис. 6. Залежність електрофізичних параметрів банкнот від ступеню їх зношення: a - поверхневий опір; б - об'ємний опір; в - ємність;

$$
\text { г - тангенс кута діелектричних втрат }
$$




\section{Список використаної літератури}

1. Киричок Т. Ю. Влияние износа на электрофизические параметры банкнот / Т. Ю. Киричок, В. М. Кириленко, Е. Г. Сухина // Известия ВУЗов. Проблемы полиграфии и издательского дела. - М., 2013. - № 6. - С. 3-12.

2. Киричок Т. Ю. Зносостійкість банкнотної продукції : монографія / Т. Ю. Киричок. - К. : НТУУ «КПІ», 2014. - 308 с.

3. Киричок Т. Ю. Аналіз зносостійкості банкнот української гривні в умовах реального обігу / Т. Ю. Киричок, А. А. Мельниченко, В.М.Нестеренко // Наукові вісті НТУу «КПІ». - 2013. — № 2(88). - С. 94-104.

4. Buitelaar T. The Colour of Soil. - DNB Cash Seminar 2008 / Amsterdam, 28-29 February, 2008. - De Nederlandsche Bank NV - Шлях доступу : http://www.dnb.nl/binaries.

5. C. Ververis. Cellulose, hemicelluloses, lignin and ash content of some organic materials and their suitability for use as paper pulp supplements / C. Ververis, K. Georghiou, D. Danielidis, D. G. Hatzinikolaou, P. Santas, R. Santas, V. Corleti // Bioresource Technology. - 2007. - Vol. 98. - P. 296-301.

6. Kyrychok Tetiana. Banknote Paper Deterioration Factors : Circulation Simulator Method / Tetiana Kyrychok, Anatolii Shevchuk, Victor Nesterenko, Petro Kyrychok // BioResources. - 2014. - Vol. 9(1). - P. 710-724.

7. IEC 60093, Methods of test for volume resistivity and surface resistivity of solid electrical insulating materials.

\section{References}

1. Kirichok, T. Ju. \& Kirilenko, V. M. \& Suhina, E. G. (2013). Vlijanie iznosa na jelektrofizicheskie parametry banknot [Influence of wear on electrophysical parameters of banknotes]. Journal of Izvestija VUZov. Problemy poligrafii $i$ izdatel'skogo dela. - News of Universities. Problems of printing and publishing, 6, 3-12 [in Russian].

2. Kyrychok, T. lu. (2014). Znosostiikist banknotnoi produktsii [The durability of banknote production]. Kyiv: NTUU 'KPI' [in Ukrainian].

3. Kyrychok, T. lu. \& Melnychenko, A. A. \& Nesterenko, V. M. (2013). Analiz znosostiikosti banknot ukrainskoi hryvni v umovakh realnoho obihu [Analysis of wear resistance of Ukrainian hryvnia banknotes in real circulation]. Journal of Naukovi visti NTUU 'KPI'. - Scientific news of NTUU 'KPI', 2(88), 94-104 [in Ukrainian].

4. Buitelaar, T. (2008). The Colour of Soil. - DNB Cash Seminar 2008. - De Nederlandsche Bank NV. Retrieved from http://www.dnb.nl/binaries [in English].

5. Ververis, C. \& Georghiou, K. \& Danielidis, D. \& Hatzinikolaou, D. G. \& Santas, P. \& Santas, R. \& Corleti, V. (2007). Cellulose, hemicelluloses, lignin and ash content of some organic materials and their suitability for use as paper pulp supplements. Journal of Bioresource Technology, 98, 296-301 [in English].

6. Kyrychok, T. \& Shevchuk, A. \& Nesterenko, V. \& Kyrychok, P. (2014). Banknote Paper Deterioration Factors: Circulation Simulator Method. Journal of BioResources, 9(1), 710-724 [in English].

7. IEC 60093, Methods of test for volume resistivity and surface resistivity of solid electrical insulating materials. 
В статье анализируется взаимосвязь электрофизических свойств образцов банкнот различных валют и степени их износа. Проведено исследование параметров, таких, как поверхностное и объемное сопротивление, емкость и тангенс угла диэлектрических потерь для банкнот трех типов валют. Результаты исследований показывают, что электрофизические свойства являются степенью износа банкнот. Определены наиболее чувствительные показатели и представлена перспектива использования электрофизических свойств банкнот с целью оценки степени их износа.

Ключевые слова: банкноты; износ; износостойкость; банкнотная бумага; электрофизические свойства.

The article analyzes the interrelation correlation of electrophysical properties of different currencies banknotes samples and there detioration stage. Research of the parameters such as surface and volume resistance, capacitance and dielectric loss tangent for three banknote currency types carried out. Banknotes electrical circuits for measuring of these indicators are shown. Research results show that electrophysical properties are a measure of degradation of banknotes. The most sensitive indicators identified. Perspective of using electrophysical properties of banknotes for evaluating of their deterioration was presented.

Keywords: banknotes; deterioration; durability; banknote paper; electrophysical properties. 